\title{
Language Shift or Maintenance? A Sociolinguistic Analysis of the Ilwana Language of Tana River County
}

Bichang'a W. Nyaigoti

\section{(2) OpenEdition}

Journals

Electronic version

URL: https://journals.openedition.org/eastafrica/839

DOI: $10.4000 /$ eastafrica.839

ISSN: 2790-1076

Publisher

IFRA - Institut Français de Recherche en Afrique

\section{Electronic reference}

Bichang'a W. Nyaigoti, "Language Shift or Maintenance? A Sociolinguistic Analysis of the Ilwana Language of Tana River County", Les Cahiers d'Afrique de l'Est / The East African Review [Online], 53।

2019, Online since 07 January 2020, connection on 09 December 2021. URL: http://

journals.openedition.org/eastafrica/839 ; DOI: https://doi.org/10.4000/eastafrica.839

This text was automatically generated on 9 December 2021.

Les Cahiers d'Afrique de l'Est / The East African Review 


\title{
Language Shift or Maintenance? A Sociolinguistic Analysis of the Ilwana Language of Tana River County
}

\author{
Bichang'a W. Nyaigoti
}

\section{Introduction}

1 The term "language shift" emerged in the 1960s in the period when Sociolinguistics was first gaining prominence as a field of study in Applied Linguistics (Fishman 1964; 1994). Yet despite its popularity and prominence in sociolinguistic literature, there exists, as of yet, no fixed definition or conceptualisation of the term. Bodomo et al (2009: 2) have broadly defined "language shift" as "a process in which successive generations of speakers, both at individual and at community levels, gradually lose proficiency in their mother-tongues or the language of their speech community in favour of other languages." This process may ultimately lead to language loss among individuals, or even language death for an entire community.

Winford (2003) notes that language shift can be the result of extensive language contact, while, on the other hand, language maintenance tends to arise from the mechanisms of borrowing and code switching. Baker and Jones (2008) have defined "language maintenance" as the promotion or protection of the native language of an individual or of a speech community. Maintenance of a language occurs when a language retains its vitality even when placed under pressure (Batibo 2005).

Previous studies of language shift and maintenance have tended to focus on cases in Western countries, yet $30 \%$ of the world's endangered languages are to be found in Africa (Bodomo et al. 2009; Nettle and Romaine 2001). Despite the global figures and reports by Unesco $(2003 ; 2009 ; 2001)$ indicating that $90 \%$ of the world's languages are 
endangered, little research has been conducted in African countries to investigate their complex linguistic ecology, which differs significantly from the Western case studies.

In Kenya, studies on language shift and/or maintenance are sparse. The Minority Rights Group (MRG) (2005: 7) states that the Ilwana language, spoken on the coastal region of Kenya in Tana River County, is one minority language out of the 42 ethnic speech communities in Kenya. The MRG further states that Kenyan minority languages are becoming increasingly endangered on account of not being taught or used in schools. Although the Ilwana language has been highlighted as an increasingly endangered minority language (Batibo 2005, Ethnologue 2015 and MRG 2005), there is no comprehensive research to authenticate this sociolinguistic status. In this sense, relying on general statistical figures and observations about the high percentage of endangered languages can be misleading. There is a need for in-depth qualitative field research to determine the precise linguistic situation.

This paper presents the findings of a sociolinguistic study that sought to investigate the extent to which the Ilwana language has undergone shift or been maintained in various domains of use. This study examined the level of language proficiency among the sampled respondents, the domain use of Ilwana, and sociolinguistic markers or indicators of language shift. This paper is divided into four main sections. First, the introduction examines the historical background of the Ilwana language and situates the study within the discourse of language shift and maintenance. Second, the research methodology and theoretical framework are examined. Third, the findings of the study and presented and analysed. Finally, a conclusion underscores the need for further research on Kenya's minority languages, documentation of the findings, and revitalisation programs.

\section{Historical Background of Ilwana and other Tana River Languages}

6 Tana River County hosts a number of Bantu and Cushitic speech communities. The dominant ones are the Pokomo and Orma, while the smaller or minority communities include the Bajuni, Waata/Sanye, Wardei, Ilwana/Malakote, Dahalo, Munyoyaya, and Somali. According to the Kenya National Bureau of Statistics (Republic of Kenya 2009) and the Population and Housing Census (2011), the Pokomo community consists of 94,965 people, Orma 70,000, Wardei 46,000 (by 2011), and Ilwana 16,800. The Munyoyaya community has a population of 15,000 , which is also associated with the Swahili community, though they speak the Orma dialect and conduct fishing along the northern part of the Tana River. The Waata/Sanye community has a population of 12,582 and is associated with the Mijikenda, both being found in Tana and Lamu. The Dahalo community consists of 2,400 people who speak Cushitic but mostly use Kiswahili, as the former is near extinction. They are found in Lamu and Tana River. The Boni/Aweer community is associated with the Mijikenda. They comprise of 7,600 people and are found in Lamu and the lower parts of Tana River. This statistical information suggests there may be an interest in examining how the complex matrix of dominant and minority languages along the Tana River have coexisted with such close association between neighbouring speech communities.

7 According to Nurse (1994: 214), existing linguistic data suggests that a three-stage historical scenario may account for the Ilwana language's genealogy. In the first stage 
(pre-1600), the Ilwana people genetically belonged to a Bantu sub-group called Sabaki, which is close to the Swahili. The Ilwana were also closely related to the neighbouring Pokomo to the south, a small southern Somali community, and various other small Cushitic groups like the Dahalo, Waata and Munyo. During the second stage (1600-1875), the Orma arrived in the Tana area in the late 17th century and settled in the hinterlands with their cattle (Martin 2007: 42). They soon dominated all the other communities along the Tana River thanks to their aggressiveness, military strength, and cultural superiority. This dominance was curtailed, however, by the entrance of the Somalis in 1875. The third stage (from 1900 onwards) was characterised by a relative calm and equilibrium. As a consequence of these three stages, the Orma settled to the west of Tana and the Somalis to the east, leaving the Ilwana and the Pokomo sandwiched between them along the river. It is claimed, however, that the Orma exerted a greater linguistic and social pressure on the Ilwana prior to 1900. Following the mid-1900s, most Ilwana speakers were reportedly bilingual, speaking both Ilwana and Orma. The Wardei started arriving in Tana Delta from 1972 onwards (Townsend 1978). This period was characterised by the highest level of language transfer, which Heine and Nurse (2008: 3) refer to as "grammatical replication." The current linguistic situation of the Ilwana and their neighbors, however, is not clearly known.

The Ilwana people are East Coast Bantus living along the banks of the Tana River in north-eastern Kenya (Nurse 1994). They currently occupy three wards in the Bura constituency: Chewele, Sala and Madogo. The Wawilwana's settlement in the early 1900s stretched nine kilometres northwards into Garissa, but by the mid-1900s the Somalis had pushed it further into the southern part of River Tana. The name "Garissa" is said to have come from a Munyoyaya man, "Garisso," who lived in the town before Europeans came to Tana River. The name "Tana" originates from the Pokomo word "Tsana" or "Chana," meaning "river," which was pronounced as "Tana" by the Europeans (Townsend 1978).

9 The Ilwana were introduced to Islam in the early $20^{\text {th }}$ century. Nurse (1994) observes that the Ilwana are fluent in both Ilwana and Kiswahili, that those who have gone to school speak English as well, while others speak Somali and Orma. Arends et al (1995) state that the "Milakote" (which came to be pronounced "Malakote") refers to a blended culture from both sides (Pokomo and Orma/Somalis/Borana). This implies that the Ilwana people have had many years of contact with the Bantu and Cushitic communities. This has influenced their language and culture. It can therefore be hypothesised that the language contact situation may have had far-reaching linguistic and socio-economic implications for the Ilwana language.

\section{The Languages surrounding Ilwana}

The Ilwana people occupy a 150-mile strip along the north-eastern part of the Tana River, bordering Garissa County. As Figure 1 illustrates, the Ilwana people are surrounded by many dominant and minority speech communities that have influenced the language in various ways. Firstly, they border the Pokomo community, with a population of some 90,000, as per the 2009 census, to the south of Tana River County. The Bantu-speaking Pokomo people occupy the Tana Delta and are divided into the Lower Pokomo (Milanchini), who are mainly Christians, and the Upper Pokomo (Milajulu), who are majority Muslim. Secondly, the Orma people, with a population of 
around 70,000, as of 2009, border the Ilwana on the western part of Tana River. They speak a Cushitic language that belongs to the Oromo family found in Ethiopia. Due to persistent attacks by Somalis, they were shielded by the Pokomo and Ilwana. Thirdly, minority speech communities also surround the Ilwana community. They include Cushitic groups such as the Sanye/Waata (population of 13,000) and the Wardei (population of 46,000 as of 2011), who co-exist with and share the language of the Orma people. The Munyoyaya or Korokoro people (population of 15,000 as of 2009), who speak a language close to Orma, occupy the land stretching from Garissa to Mbalambala on the northern side of River Tana. Finally, while bordering the Somali community that occupies the eastern part of Tana River, the Ilwana people also co-exist with some Somali immigrants living in Tana River regions like Madogo and Bura.

Figure 1: Speech communities neighbouring Ilwana

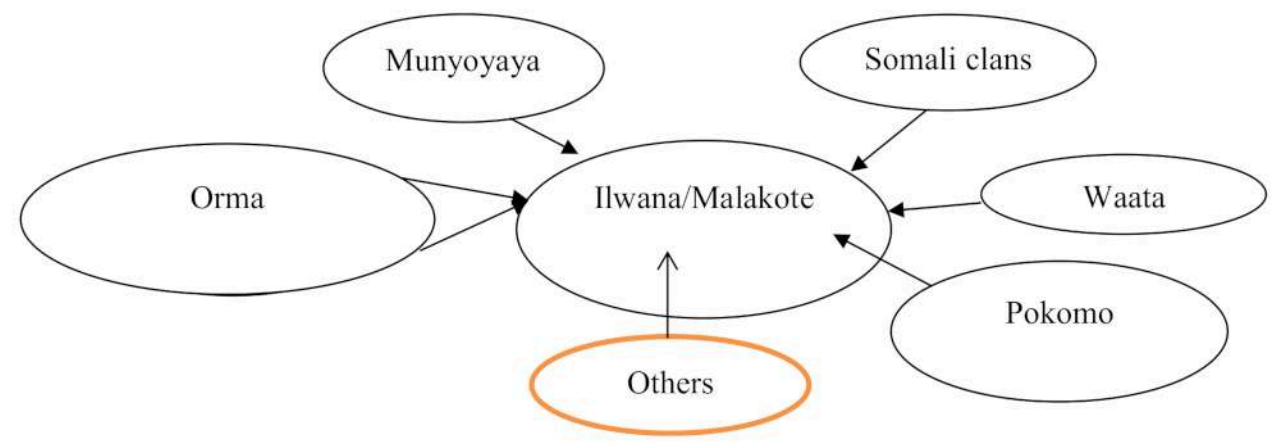

11 In Figure 1, above, it can be seen that there are some six speech communities neighbouring the Ilwana people. There is also, however, a seventh category of minority languages (such as Bajuni, Dahalo and Boni) with a very small number of speakers, although their influence on the Ilwana is insignificant as the languages have become extinct. These neighbouring speech communities have exerted enormous socioeconomic and linguistic pressure on the Ilwana community, potentially leading to the decline of the language in domain use (Nurse 1994). As most socio-economic and religious facilities are shared, including common market centres, schools, health centres, government offices and mosques, it is necessary to use the lingua franca, especially Kiswahili, for communicative purposes. The language contact situation and the sociolinguistic influence of these communities on the Ilwana language have, nonetheless, not been subject to comprehensive research and documentation. This scenario prompts the following question: how has the language contact situation contributed to Ilwana language shift and/or maintenance?

\section{Research Methodology}

\section{Sample Demographics}

The study sample consisted of 100 Ilwana respondents residing in Chewele, Sala and Madogo. It was not feasible to select the informants randomly, and some variables such as educational background, occupation, and age were not represented equally for various reasons. Firstly, there are no official government records that differentiate 
Ilwana speakers in terms of age, occupation, gender, or educational background. Secondly, there are no Ilwana, Orma or Pokomo clubs or organisations through which the researcher could make direct contact with individual members of the community. Thirdly, the topic seemed to be very sensitive for most people of Ilwana origin owing to their minority status, meaning some were hesitant to respond to questions. Purposive sampling and a social networking model were used through a friend of a friend. Tables 1 and 2 present the demographic characteristics of the informants by age, gender, occupation and education background.

Table 1: Distribution of the sample by age

\begin{tabular}{|l|l|}
\hline Age & No. of respondents \\
\hline $5-10$ & 0 \\
\hline $11-20$ & 37 \\
\hline $21-30$ & 35 \\
\hline $31-40$ & 18 \\
\hline $41-50$ & 4 \\
\hline $51-60$ & 4 \\
\hline $61+$ & 2 \\
\hline Total number of respondents & 100 \\
\hline
\end{tabular}

Table 2: Distribution of the sample by gender

\begin{tabular}{|l|l|}
\hline Gender & No. of respondents \\
\hline Males & 54 \\
\hline Females & 46 \\
\hline Total number of respondents & 100 \\
\hline
\end{tabular}

Table 3: Distribution of the sample by occupation

\begin{tabular}{|l|l|}
\hline Occupation & No. of respondents \\
\hline Students & 40 \\
\hline Teachers & 4 \\
\hline Civil servants & 4 \\
\hline Police & 3 \\
\hline Homemakers & 22 \\
\hline Drivers & 4 \\
\hline Nurses & 4 \\
\hline Craftsmen & 5 \\
\hline
\end{tabular}




\begin{tabular}{|l|l|}
\hline Mechanics and technicians & 5 \\
\hline Traders & 2 \\
\hline Shop assistants & 3 \\
\hline Retired & 1 \\
\hline No occupation & 3 \\
\hline Total number of respondents & 100 \\
\hline
\end{tabular}

Table 4: Distribution of the sample by educational background

\begin{tabular}{|l|l|}
\hline Educational background & No. of respondents \\
\hline Illiterate & 3 \\
\hline Standard 1-8 & 15 \\
\hline Form 1-4 & 52 \\
\hline College education & 16 \\
\hline University education & 14 \\
\hline Total number of respondents & 100 \\
\hline
\end{tabular}

\section{Data Collection}

13 The data was collected using the Swadesh wordlist of 100 lexical items, as well as interview schedules, personal observations, and structured questionnaires. This process was supported by research assistants, community leaders and village heads, who all helped in the distribution of questionnaires and the organisation of face-to-face interview schedules. The questionnaire was designed to collect data on language use in various domains, as well as attitudes towards and degree of proficiency in Ilwana, Kiswahili, and any other Tana River languages. The data was coded, transcribed and analysed qualitatively.

\section{Theoretical Framework}

This study was guided by Fishman's (1964) domain theory and Matras' (2009) theory of language contact. The domain theory is grounded on the maxim: who speaks what language when and where (Fishman 1991). The who premise is used to identify speakers (such as the Ilwana of Tana River and surrounding speech communities), the what question is used to refer to the dialect(s) under study (for example, the Ilwana and neighbouring dialects), while when refers to the time of interaction, and where to the locales of interaction or domains of language use. The domains or contexts of language use include the home, school, market, office, public or communal functions, religious situations, and so forth. This theory was particularly important for the analysis of the data collected on Ilwana language proficiency and language use in different domains. 

multilingual and most people speak two or more languages. "Language contact" is defined as sociolinguistic situations that characterise the interaction of speakers of different languages, thereby leading them to influence one another (Matras 2009: i). The central arguments of the framework hinge on the analysis of sociolinguistic aspects such as language convergence, code-switching in conversation, replication of linguistic matter or language transfer, lexical borrowing, grammatical and phonological borrowing, and mixed languages. language contact in the realm of language and communication. The ultimate result of language contact is that it may lead to language change when a borrowed linguistic element is accepted and becomes commonplace. In this way, the morpho-syntactic constructions, collective language learning and use of loanwords lead to language convergence. Of great concern to the study are three sociolinguistic aspects of the contact-induced influence on language and multilingual or bilingual status: lexical borrowing, language transfer or replication, and code-switching.

\section{Sociolinguistic Aspects of the Contact-Induced Influence on Language and Multilingual or Bilingual Status}

\section{Lexical Borrowing}

Matras (2009) argues that the Swadesh list is a lexico-statistical method that mainly establishes genetic relatedness of different languages rather than determining the stability of vocabulary in situations of contact. Nouns are more prominent among borrowed lexical word classes, as made evident by existing statistics on borrowing. The high frequency of noun loan words in any language can be attributed to their referential functions in naming concepts, objects, activities and roles. It is on this note that the study examined lexical borrowing as a key sociolinguistic aspect of the language contact situation between Ilwana and other Tana River languages. The study did not examine grammatical and phonological borrowing among the native languages.

\section{Pattern Replication or Transfer}

A distinction is made between borrowing and replication. Matras (2009) states that the former focuses too much on ownership and boundaries between the linguistic items involved. Replication is considered as a dynamic process of sharing a structure or word-form, adopting, applying and using it: the nativisation of a structure or pattern. The terms "copying" or "language transfer" refer to the creative use of an item within the recipient language. As Matras (2009: 238) states: "Pattern replication is characterised as a change to an inherited structure of the 'replica' language, inspired by a structure of the 'model language'." This may result in a change of meaning.

\section{Code-Switching}

This sociolinguistic aspect is defined differently by different scholars. Some define it as the use of different languages within an utterance, conversational exchange, or phrase. Others argue that code-mixing refers to unique morphological structures derived from 
the blending of morphemes from different languages. These divergent definitions can nonetheless remain contained by the single term.

A distinction is commonly made between "alternational" code-switching alternating languages between utterances or sentences-, and "insertional" codeswitching-the insertion of a word or phrase into an utterance or sentence formed in a particular base or frame language. (Matras 2009: 119)

These three sociolinguistic aspects play a key role in analyzing the extent to which the Ilwana language has undergone shift or been maintained in various contexts.

\section{Analysis of Data and Discussion}

Analysis of the data is presented in three main sub-sections: analysis of language proficiency, domain use and sociolinguistic aspects, and their contribution to language shift and/or maintenance.

\section{Language Proficiency}

Table 5 represents the "can" questions that assess the informants' proficiency in Ilwana and Kiswahili. The table elicits data on the informants' abilities to listen, speak, read, and write in both languages. The informants were asked to rate their language ability in the four language areas on a three-point scale. The possible question responses were "Yes," "No," and "A little."

Table 5: Response percentages: Language proficiency in Ilwana and Kiswahili

\begin{tabular}{|l|l|l|l|l|}
\hline No. & Language skills & $\begin{array}{l}\text { Yes } \\
(\%)\end{array}$ & $\begin{array}{l}\text { No } \\
(\%)\end{array}$ & $\begin{array}{l}\text { A little } \\
(\%)\end{array}$ \\
\hline 1. & Can you understand a conversation in Ilwana & 50 & 27 & 23 \\
\hline 2. & Can you engage in a conversation in Ilwana & 43 & 39 & 12 \\
\hline 3. & Can you read a text in Ilwana & 19 & 69 & 12 \\
\hline 4. & Can you write in Ilwana & 14 & 76 & 10 \\
\hline 5. & Can you understand Kiswahili & 98 & 0 & 2 \\
\hline 6. & Can you read a text in Kiswahili & 96 & 3 & 1 \\
\hline 7. & Can you write in Kiswahili & 95 & 4 & 1 \\
\hline 8. & $\begin{array}{l}\text { Can you speak any of Tana River languages e.g. Pokomo or } \\
\text { Orma }\end{array}$ & 15 & 75 & 10 \\
\hline
\end{tabular}

The findings clearly demonstrate that the respondents rated their language abilities in Kiswahili significantly higher than their Ilwana language proficiency. $98 \%$ of the respondents could understand a conversation in Kiswahili, whereas only 50\% could understand a conversation in Ilwana. Interestingly, $96 \%$ and $95 \%$ of informants could read and write in Kiswahili respectively. However, they rated their Kiswahili speaking ability higher than their writing or reading abilities. While $43 \%$ could engage in a conversation in 
Ilwana, only $19 \%$ and $14 \%$ of them could read and write in Ilwana respectively. This could be attributed to the fact that there are no schools in the Bura Constituency that offer the curriculum delivered in Ilwana language. Kiswahili and English are the official languages of the school domain and the languages of instruction in schools. On this matter, Gracia (2003: 27-28) writes, "When coupled with schooling that pays no attention to teaching reading and writing in the ethnic home language, resultant exposure to that language is minimal and productive skills in the language are severely limited." It can be argued that the Ilwana speakers' language proficiency in Ilwana has been decreasing with each generation, while there has been a remarkable increase in Kiswahili proficiency. This leads to the conclusion that the Ilwana language has been going through a gradual language shift.

\section{Language use}

Table 6: Response percentages: Language use in different domains

\begin{tabular}{|c|c|c|c|c|c|c|c|}
\hline Questions & $\begin{array}{l}\text { Only } \\
\text { Kisw. }\end{array}$ & $\begin{array}{l}\text { Mostly } \\
\text { Kisw. }\end{array}$ & $\begin{array}{l}\text { Kisw. \& } \\
\text { Ilwana }\end{array}$ & $\begin{array}{l}\text { Mostly } \\
\text { Ilwana }\end{array}$ & $\begin{array}{l}\text { Only } \\
\text { Ilwana }\end{array}$ & $\begin{array}{l}\text { No } \\
\text { response }\end{array}$ & Total \\
\hline $\begin{array}{l}\text { 1. What language do you use } \\
\text { when writing SMS or letters? }\end{array}$ & 78 & 3 & 19 & - & - & - & 100 \\
\hline $\begin{array}{l}\text { 2. What language do you use } \\
\text { when you speak with your } \\
\text { neighbours? }\end{array}$ & 10 & 10 & 20 & 47 & 12 & - & 100 \\
\hline $\begin{array}{l}\text { 3. What language do use you } \\
\text { when speaking with your } \\
\text { children? }\end{array}$ & 13 & 14 & 22 & 20 & 31 & - & 100 \\
\hline $\begin{array}{l}\text { 4. What language do you use } \\
\text { with your parents and the } \\
\text { elderly? }\end{array}$ & 12 & 11 & 22 & 14 & 41 & - & 100 \\
\hline $\begin{array}{l}\text { 5. What language do you use } \\
\text { at home with your brothers } \\
\text { and sisters? }\end{array}$ & 15 & 13 & 20 & 19 & 33 & - & 100 \\
\hline $\begin{array}{l}\text { 6. What language do you use } \\
\text { during Ilwana social } \\
\text { occasions? }\end{array}$ & 16 & 10 & 20 & 24 & 30 & - & 100 \\
\hline $\begin{array}{l}\text { 7. What language do you use } \\
\text { when you meet friends in the } \\
\text { neighbourhood? }\end{array}$ & 13 & 12 & 23 & 20 & 32 & - & 100 \\
\hline $\begin{array}{l}\text { 8. What language do you use } \\
\text { when you meet friends at } \\
\text { school or university? }\end{array}$ & 68 & 25 & 5 & 2 & - & - & 100 \\
\hline
\end{tabular}




\begin{tabular}{|l|l|l|l|l|l|l|l|}
\hline $\begin{array}{l}\text { 9. What language do you use } \\
\text { in official functions or in the } \\
\text { workplace? }\end{array}$ & 70 & 26 & 4 & - & - & - & 100 \\
\hline $\begin{array}{l}\text { 10. What language do you use } \\
\text { when invoking or praying? }\end{array}$ & 76 & 21 & 3 & - & - & - & 100 \\
\hline $\begin{array}{l}\text { 11. What language do you use } \\
\text { when buying goods from a } \\
\text { shop or market? }\end{array}$ & 66 & 32 & 2 & - & - & - & 100 \\
\hline
\end{tabular}

Table 6 shows that the majority of the respondents tend to use Ilwana predominantly in the family, neighbourhood or home domains or contexts, to varying degrees, while Kiswahili is used in formal contexts, especially at school and during official functions. Questions 3, 4 and 5 show that there is a general trend among family members to communicate with each other in Ilwana. More specifically, $21 \%$ of the respondents tend to use "only Ilwana" when speaking to their children, whereas only $13 \%$ of them tend to use "only Kiswahili." Moreover, 33\% of the respondents tend to use "only Ilwana" at home when speaking to their brothers and sisters, whereas 15\% use "only Kiswahili." This demonstrates that, over time, Kiswahili is starting to overtake Ilwana for usage in the home domain. It seems that some parents do not have the willingness or desire to pass on Ilwana to their children. This is a significant indication that Ilwana is likely to rapidly fade away in the next generation or two. Such a conclusion is consistent with Fishman's (1991: 2000b) assertions that a basic principle for ensuring the maintenance of an ethnic language is to enforce and encourage its use at home and in the community.

With regards to the community, and as indicated in questions $2,6,7$, and 8 , it is evident that Ilwana is used as a medium for social interactions with neighbours (47\%), at Ilwana social occasions (30\%), and with friends in the neighbourhood (32\%). However, with friends at school or at university (88\%), Kiswahili (68\%) is predominantly used instead. If we argue that the relative purpose of Kiswahili and Ilwana use in questions 2 and 8 is to fulfil social needs, that is, to communicate effectively and to be better understood by Ilwana people, then the fairly dominant but declining use of Ilwana in social and formal occasions-"only Ilwana" (12\% versus $0 \%)$, "mostly Ilwana" (47\% versus $2 \%)$, "Kiswahili and Ilwana" (20\% versus $5 \%$ ) - could be interpreted in one of two ways. Firstly, Ilwana speakers are rapidly regressing in their spoken use of their ethnic language and Kiswahili is gradually replacing it. Alternatively, there has been a change in the Ilwana identity. The Kiswahili language is prestigious and the use of Ilwana is stigmatised in the community, especially among students and the educated or working class. As Mugaddam (2006: 129) notes, minority indigenous language speakers tend not to use their own languages in public cosmopolitan contexts for fear of being stigmatised. By speaking and communicating in Kiswahili, they show that they are part of the Bantu nation, or, as they express it in local terms, watu wenye ungwana ama watu wangwana, that is, "polite" or "kind" people.

27 To quote one of the students whom we interviewed about this issue, “... though I am a Malakote, Madogo is my hometown. I was born in Madogo and my grandparents fought with the Somali Shifta." The Shifta was a heterogeneous Somali militia that agitated for 
the secession of the North-Eastern Province in the 1960s and 1970s, at a time known as the "Shifta War." The results also indicate that $78 \%$ of the Ilwana people tend to use Kiswahili for writing personal letters, $19 \%$ tend to use Kiswahili and Ilwana, but none use only Ilwana. This finding is consistent with our previous claim that there is no additional or language-specific educational support given to the Ilwana people. This means that their writing and reading skills in that language are severely limited. We can also infer that the language inherited from parents and elderly people is passed on orally, and not in written form. Finally, it is not surprising that Kiswahili, and to a large extent Arabic, are the languages used when praying and invoking. This use of Arabic is common among Muslims, whether Arab or otherwise, as Arabic is considered the language of worship and prayer.

\section{Sociolinguistic Aspects}

Relying on the integrated theory of language contact, the study identified and analysed three sociolinguistic aspects as indicators of language shift: lexical borrowing, language transfer and code-switching. These aspects are examined below.

\section{Lexical Borrowing}

This sociolinguistic concept is examined at various levels of cross-linguistic analysis. First, between Ilwana and Pokomo. Second, between Bantu and Cushitic languages in Tana River. Third, among Cushitic languages.

Previous studies have documented the extensive borrowing from Cushitic Orma and Kiswahili lexical items in the Ilwana language (Nurse 1994, Heine \& Nurse 2008: 215). The data in our corpus validates the argument that Ilwana is a mixed language. In reference to the Swadesh 100 wordlist (see table 7 below), a few examples have been extracted for illustration.

Table 7: Lexical relationship among Tana River languages

\begin{tabular}{|c|c|c|c|c|c|}
\hline & Noun & Ilwana Sing. - Pl. & Pokomo Sing. - Pl. & Orma Sing. - Pl. & Somali Sing. - Pl. \\
\hline 1. & woman & $\begin{array}{l}\text { moka } \\
\text { wakamwale }\end{array}$ & muke - wake & naden - naden & $\begin{array}{l}\text { dumar - haween/ } \\
\text { haweeno }\end{array}$ \\
\hline 2. & $\operatorname{man}$ & molome - mwali & mulume - walume & $\begin{array}{l}\text { namich/diir } \\
\text { namich /diir }\end{array}$ & $\mathrm{rag} / \mathrm{nin}$ - nimano \\
\hline 3. & person & modo - dagha & mutu - wantu & nam - inama & qof - ruux \\
\hline 4. & fish & seh - seh & nisu -nisu & qurtumi - qurtumi & malaay - malaay \\
\hline 5. & bird & nyoni - nyoni & nyuni - nyuni & $\begin{array}{l}\text { shimpire } \\
\text { shimpire }\end{array}$ & $\begin{array}{l}\text { shimbir } \\
\text { shimbiro }\end{array}$ \\
\hline 6. & louse & jawa-jawa & nchawa - nchawa & hinjiran - hinjiran & injir - injir \\
\hline 7. & tree & mote - miti & muhi - mihi & $\begin{array}{l}\text { muk - muk mukh - } \\
\text { mukhean }\end{array}$ & geedh - geedho \\
\hline
\end{tabular}




\begin{tabular}{|c|c|c|c|c|c|}
\hline 8. & seed & beu-beu & mbeyu - mbeyu & $\begin{array}{l}\text { beyu - beyu guma - } \\
\text { guma }\end{array}$ & abuur - abuur \\
\hline 9. & root & $\begin{array}{l}\text { hida - hidena } \\
\text { moze - meze }\end{array}$ & muzi - mizi & $\begin{array}{l}\text { hidh - hidhena } \\
\text { hidh -hidh }\end{array}$ & $\begin{array}{l}\text { xidhidh } \\
\text { xidhidho }\end{array}$ \\
\hline 10. & bark & ipada - mapada & kafi - makafi & qoi - qoi & qolof - qolfa \\
\hline 11. & skin & gogha-gogha & $\begin{array}{l}\text { nkingo - nkingo } \\
\text { gogha - gogha }\end{array}$ & $\begin{array}{l}\text { goga -goga goga - } \\
\text { gogole }\end{array}$ & maqaar - maqaaro \\
\hline 13. & bone & mufupa - mifupa & mufupha -mifupha & lafen - lafen & laf - laf \\
\hline 14. & egg & imayi - mayi & igi - magi & okokan - okokan & ukun - ukumo \\
\hline 15. & tail & mkila - mikila & mkila - mikila & ege - ege & seeyn - seema \\
\hline 16. & blood & sakame - sakame & digha-digha & dig-dig & $\begin{array}{l}\text { gooryaan } \\
\text { gooryamo }\end{array}$ \\
\hline 17. & grease & grisis - grisi & bada - mabada & gris - gris & gris - gris \\
\hline 18. & animal & binesa - binesa & binisa - binisa & bines -bines & $\begin{array}{l}\text { xawayan } \\
\text { xawayan }\end{array}$ \\
\hline 19. & head & kechwa - bhichwa & kichwa - vichwa & matta - matta & $\begin{array}{l}\text { madhax } \\
\text { madhaxyo }\end{array}$ \\
\hline 20. & ear & isikilo-masikilo & sikilo-masikilo & gur - guren & dag - dago \\
\hline 21. & eye & izicho - macho & jicho - macho & ill - ill & il - indo \\
\hline
\end{tabular}

Example 8: the word for "seed" is "beu" in Ilwana and "mbeyu" in Pokomo. This same form is replicated in Orma and Munyoyaya, where the variant "beyu" is used. It can be argued that since Bantus are historically known to be farmers, while Cushites were nomadic pastoralists, the word was borrowed from the Bantu lexical form.

Example 9: the Orma word for "root" is "hidh" (singular) and "hidhena" (plural), while the Ilwana equivalents are "hida" and "hidena." This same lexical form is found in all the Cushitic languages. Only Pokomo, a Bantu language, does not use this form. However, it can be observed that the Cushitic morphological form " $d h$ " is elided in the Ilwana language. This is in line with the phonological rule that states that, where a consonant exists in the foreign language (Cushitic), and in the absence of a vowel, the Ilwana language inserts a vowel. This is illustrated below:

$$
\varnothing \rightarrow[+ \text { Cons. }] / \mathrm{V}-\mathrm{V}
$$

Some words, which were possibly borrowed from Cushitic Orma, are given an additional letter $h$, e.g. "gogha" in Ilwana as compared to "goga" (skin) in Orma and Munyoyaya (Example 11).

In Example 16, the Pokomo have borrowed the word "digh," meaning "blood," from either the Orma or the Wardei form "dig." 
The data in our corpus also reveals that some words have been borrowed from English and directly translated into the indigenous language, for example, "grisi" (grease) (Example 17).

Example 18 shows related lexical forms (cognates) among Bantu and some Cushitic languages, for example, the word "animal," which is "binesa" in Ilwana, "binisa" in Pokomo, and "bines" in Orma.

Overall, six out of the 60 nouns in the corpus (10\%) appear in at least seven of the eight Tana River languages under our study.

It is also worth noting the discernible correlation between Ilwana and Pokomo lexical items. This phenomenon may not be surprising as they are both East-Coast Bantu peoples belonging to the Sabaki sub-group. 23 of the 60 words (38\%) are cognates. Examples include:

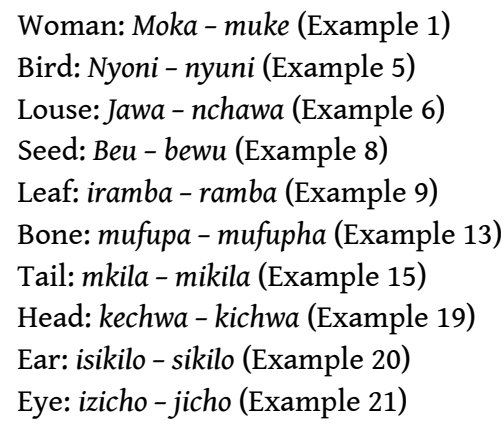

In view of the above, this paper argues that, despite the common ancestry, the Ilwana language seems to have heavily borrowed from Pokomo besides Orma and Kiswahili. This argument is informed by the Ilwana language's minority status and the socioeconomic and linguistic dominance of the more populous speech communities.

Notably, there was also noted an instance of borrowing from Kiswahili through a receptor language, like Pokomo, as seen in examples 13, 25 and 21 above.

Moreover, Marhan and Somali have equally similar lexical forms, and Marhan is considered a dialect of the Somali language. For instance, 35 out of 60 nouns (58\%) in our corpus are cognates, which would appear to validate the claim that they share a common ancestry. Similarly, Orma and Munyoyaya are closely related, as suggested by the 43 cognates out of 60 words (71\%).

\section{Pattern Replication or Language Transfer}

Replication (as discussed in Section 2 above) involves the act of copying a grammatical aspect or syntactical feature. As a mixed language, Ilwana copies Cushitic plural forms. For example, the following singular and plural forms do not conform to the Bantu noun class system.

Man: molome - mwali

Person: modo - dagha

The word "molome" for "man" belongs to Class 1 , but the plural form does not exhibit the Class 2 plural marking. The same applies in the case of the second example.

Cushitic affixes in Ilwana consist of four plural markers as exemplified by: "-ena,"“-era,"

“-waki," and "-imo" below:

-ena: ngoma (drum) - ngomena (drums)

hida (root) - hidena (roots)

Les Cahiers d'Afrique de l'Est / The East African Review, 53 | 2019 


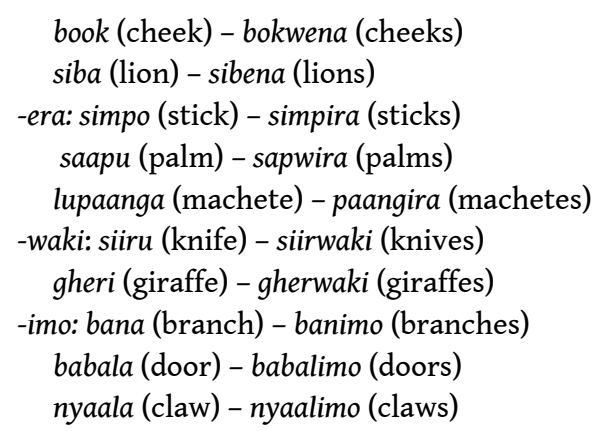
government services, workplaces, and even religious functions. As a result, codeswitching normally occurs in shared socio-economic domains. Moreover, codeswitching is commonplace among young people, who select from their rich linguistic repertoire a set of lexical items of their choice in order to communicate with their peers. The Ilwana case study is a good example of this (as illustrated by Table 8, below). 
51 This sociolinguistic survey of the current state of the Ilwana language reveals two fundamental observations. Firstly, it demonstrates that there is significant language variation between the younger and older population groups. Secondly, it reveals that there has been a sharp decline in the use of Ilwana in various domains. The first scenario highlights the intergenerational language variation which is an apparent indicator of internal shift. This in turn may have been occasioned by contact-induced influence from other neighbouring languages. Where the older generations speak mostly Ilwana amongst themselves, the young people prefer code-switching, particularly in social interactions, as shown in Table 8 below.

Table 8: The Ilwana Lexical Choices across Generations

\begin{tabular}{|c|c|c|c|c|}
\hline $\begin{array}{l}\text { Language used by } \\
\text { younger generations }\end{array}$ & $\begin{array}{l}\text { Language used by } \\
\text { the middle-aged }\end{array}$ & $\begin{array}{l}\text { Language used by } \\
\text { older generations }\end{array}$ & $\begin{array}{l}\text { Kiswahili } \\
\text { form }\end{array}$ & English gloss \\
\hline 1.a) NA & moka wangu & moka wemi & mke wangu & my wife \\
\hline b) N/A & moka wetu & wakamwale wetu & wake wetu & our wives \\
\hline 2. a) modo huyu & modo oyo & modo oyo & mtu huyu & $\begin{array}{l}\text { this man or } \\
\text { person }\end{array}$ \\
\hline b) modo hawa & dagha hawa & dagha hawa & watu hawa & These people \\
\hline 3. bwa - bwahera & bwa - bwa & bwa - bwa & $\begin{array}{l}\text { mbwa } \\
\text { mbwa }\end{array}$ & dog-dogs \\
\hline 4. luala - luala & luala - luala & lokobe - gobe & $\begin{array}{l}\text { kucha } \quad- \\
\text { kucha }\end{array}$ & $\begin{array}{l}\text { fingernail - } \\
\text { fingernails }\end{array}$ \\
\hline 5. seh - sehera & seh - seh & seh-she & $\begin{array}{ll}\text { samaki } & - \\
\text { samaki } & \end{array}$ & fish - fish \\
\hline 6. mti-miti & mote - miti & mote - miti & mti - miti & tree - trees \\
\hline 7. kichwa - vichwa & kichwa - vichwa & kechwa - bhichwa & $\begin{array}{ll}\text { kichwa } & - \\
\text { vichwa } & \end{array}$ & head - heads \\
\hline 8. sikio - masikio & isikilo - masikilo & isikilo - masikilo & $\begin{array}{ll}\text { sikio } & - \\
\text { masikio } & \end{array}$ & ear - ears \\
\hline 9. jicho - macho & izicho - macho & izicho - macho & $\begin{array}{l}\text { jicho } \\
\text { macho }\end{array}$ & eye - eyes \\
\hline 10. mfupa - mifupa & mfupa-mifupa & mufupa - mifupa & $\begin{array}{l}\text { mfupa } \quad- \\
\text { mifupa }\end{array}$ & bone - bones \\
\hline 11. mbegu - mbegu & beu - beu & beu - beu & $\begin{array}{l}\text { mbegu }- \\
\text { mbegu }\end{array}$ & seed - seeds \\
\hline
\end{tabular}

52 From the above examples, a difference can be seen between the younger and older generations in their use of singular and plural forms. In examples 1 and 2, the younger generations use moka and modo for both singular and plural forms, instead wakamwale and dagha, respectively. In Example 1, the singular noun moka (wife) is combined with 
the Kiswahili possessive form wangu, instead of wemi (my). The same can be said of modo huyu being used instead of modo oyo (Example 2.a.). In Example 3, the younger generations use a different plural form, bwahera (dogs), instead of bwa, for both the singular and plural forms (dog or dogs). In Example 4, they incorrectly use luala, instead of lokobe, to refer to a person's fingernails. Luala refers, in fact, to a lion's claws. Furthermore, Example 5 shows that the younger generations use seh (fish) in the singular form, and sehera (fish) for the plural form. This is contrary to the norm, where the word seh is used for both the singular and plural form.

The above examples demonstrate that the younger generations prefer a mixture of Ilwana and Kiswahili. This is shown by examples 1 and 2. They also tend to add the plural morpheme "-era" to the noun stem or base, contrary to the norm, as shown by examples 3 and 5 above. These examples indicate that a gradual internal language shift is occurring, as exemplified by the adoption of Kiswahili lexical items (through codeswitching), lexico-semantic change, and morphological restructuring among the younger generations. This internal shift is an indicator that the language is highly unstable and undergoing systematic shift from one generation to the next.

In terms of domain use, the Ilwana language is mostly used at home and at certain communal social events. Due to shared socio-economic facilities, it is not used in schools, religious discourse, government offices, or formal meetings. This scenario has been influenced by neighbouring languages exerting enormous pressure on the Ilwana language. This has led to a sharp decline in the domain usage.

\section{Conclusion}

In this paper, we have examined the notions of language shift and/or maintenance in the context of Ilwana language use. The research has revealed that Ilwana speakers are gradually shifting towards the use of Kiswahili. Based on the respondents' answers to the questionnaire and information disclosed in interviews, the shift may be attributed to the following causes:

Firstly, the many years of marginalisation by successive Kenyan independent governments, along with some three centuries of language contact with both Bantu and Cushitic speech communities, leading to a reduced domain use of Ilwana and declining proficiency, especially among the younger generations. The majority of the Ilwana vocabulary has been borrowed from neighbouring languages, as demonstrated in Table 7.

Secondly, the research findings indicate that the declining use of Ilwana at home and in the community may be attributed to the little effort being made by parents to encourage the use of Ilwana in their children. From this evidence it may be hypothesised that the proficiency of the next generation will be severely limited. This is consistent with Fishman's (1991) assertion that, for an ethnic language to be maintained, concerted efforts must be made to enforce it at home and in the community.

Thirdly, the language shift has been accelerated by two major forces, one being internal factors characterised by the limited domain use and declining proficiency of Ilwana due to the growing influence of Kiswahili as a regional lingua franca, as well as the negative attitude of the younger generations-particular students and the well-educated- 
towards speaking Ilwana. The second force concerns the external sociolinguistic and economic factors resulting from language contact with surrounding communities. The language contact situation has had a major impact on pattern replication, with massive borrowing from dominant neighbouring languages like Pokomo and Orma occurring. This has made Ilwana emerge as a language that unites the Northern/Cushitic and Southern/Bantu linguistic varieties, as argued by Nurse (1994). This is a manifestation of inter-ethnic tolerance, mutual integration and peaceful co-existence among the Ilwana and surrounding speech communities.

Finally, this research paper concludes that for the Ilwana language to be maintained and enhanced in its usage across various contexts, there must be institutional support from the government and NGOs for the promotion of language revitalisation programmes. These could include teaching Ilwana language literacy in lower primary levels, adult literacy classes, and the printing and distribution of study materials, as just some example. Furthermore, if the Ilwana people were listed as a distinct ethnic group in the Kenyan national census, the Ilwana language could be more effectively maintained. Finally, further research needs to be conducted on the phonological, morphological, syntactical and semantical structure of the Ilwana language.

\section{BIBLIOGRAPHY}

Baker, C. \& S.P. Jones. 1998. Encyclopaedia of Bilingualism and Bilingual Education. England: Clevedon. Batibo, H.M. 2005. Language Decline and Death in Africa. Causes, Consequences and Challenges. Clevedon, UK: Multilingual Matters Ltd.

Bodomo, A., J. Anderson, \& J. Dzahene-Quarshie. 2009. “A Kente of Many Colours: Multilingualism as a Complex Ecology of Language Shift in Ghana." Journal of Sociolinguistic Studies: Special Issue on Language Shift 3 (3). https://journals.equinoxpub.com/SS/article/view/6339 [archive].

Ethnologue 18th ed. 2015. "Ilwana Language at Ethnologue." http://www.ethnologue.com/18/ language/tec/ [archive].

Fishman, J.A. 1964. "Language Maintenance and Language Shift as a Field of Enquiry." Linguistics, no. 9, 32-70.

Fishman, J.A. 1991. Reversing Language Shift: Theoretical and Empirical Foundations of Assistance to Threatened Language. Clevedon-England: Multilingual Matters.

Garcia, M.E. 2003. "Recent Research on Language Maintenance.” Annual Review of Applied Linguistics, no. 23 .

Heine, B. \& Nurse, B., eds. 2008. A Linguistic Geography of Africa. New York: Cambridge University Press.

"Ilwana Language." S.d. Wikipedia. https://en.wikipedia.org/wiki/Ilwana_language. Accessed 20 January 2018 
Martin, P. 2007. Conflict and its Socio-economic Impact in Garsen Division, Tana River District. Eldoret: Moi University.

Matras, Y. 2009. Language Contact. Cambridge: Cambridge University Press.

Minority Rights Group International. 2005. Kenya: Minorities, Indigenous Peoples and Ethnic Diversity. Nairobi: MRG.

Mugaddam, A.R. 2006. "Language Maintenance and Shift in Sudan: The Case of Migrant Ethnic Groups in Khartoum.” International Journal of the Sociology of Language, no. 181 (2006).

Nettle, D. \& Romaine, S. 2000. Vanishing Voices: The Extinction of the World's Languages. Oxford: Oxford University Press

Nurse, D. 1994. "South Meets North: Ilwana = Bantu + Cushitic on Kenya's Tana River." In Mixed Languages: 15 Case Studies in Language Intertwining, edited by P. Bakker \& M. Mous: 213-228. Amsterdam: IFOTT.

Republic of Kenya. 2009. 2009 Kenya Population and Housing Census, Vols. 1-4, Nairobi: Government Press.

Townsend, N. 1977. “Age, Descent and Elders among the Pokomo.” Africa: Journal of the International African Institute 47 (4): 386-97.

Unesco. 2003 "Language Vitality and Endangerment." Document Submitted to the International Expert Meeting on Unesco Programme for Safeguarding Endangered Languages, Paris. 1012 March 2003. http://www.unesco.org/new/fileadmin/MULTIMEDIA/HQ/CLT/pdf/ Language_vitality_and_endangerment_EN.pdf [archive].

Unesco. 2009. Unesco Atlas of the World's Languages in Danger. Paris: Unesco. http:// www.unesco.org/languages-atlas/ [archive].

Unesco. 2001. Universal Declaration on Cultural Diversity. Paris: Unesco. http://portal.unesco.org/ en/ev.php-URL_ID=13179\&URL_DO=DO_TOPIC\&URL_SECTION=201.html [archive].

Winford, D. 2003. An Introduction to Contact Linguistics. Oxford: Blackwell Publishing Ltd.

\section{ABSTRACTS}

Tana River County is home to a number of Bantu and Cushitic speech communities. The dominant groups are the Pokomo and the Orma, while other groups include the Waata/Sanye, Wardei, Ilwana/Malakote, Dahalo, Munyo-yaya, and some Somalis. Of significant interest to this study is the Ilwana language, which incorporates a unique linguistic blend of the Bantu and Cushitic languages. This paper presents research findings about the extent to which the Ilwana language has undergone language shift or maintenance. It focuses on Ilwana proficiency, the domain use of this language, and sociolinguistic indicators about language shift and/or maintenance. Findings suggest that the Ilwana language is gradually shifting towards Kiswahili, and that it is predominantly used at home and in a few communal gatherings and events. The results further reveal that there are significant linguistic similarities (cognates) with the neighbouring Pokomo and the Cushitic Orma languages. Some of the lexical items also show signification correlation with certain Kiswahili words. Lexical borrowing, language transfer and code-switching are thus considered clear indicators of the linguistic blending that characterises the many decades of language contact between the Ilwana and other Tana River ethnic groups. In this sense, this paper argues that indigenous languages demand greater documentation as they 
play a fundamental role in promoting cultural preservation, collective and individual identity, and regional and national cohesion.

INDEX

Keywords: language shift, language maintenance, sociolinguistic analysis, Ilwana language, Tana River County

Geographical index: Kenya 